\title{
Cardiorenal Consequences of Dual Angiotensin Converting Enzyme and Neutral Endopeptidase 24.11 Inhibition in Transgenic Rats with an Extra Renin Gene
}

\author{
Max Wegner, Claudia Hirth-Dietrich, Andreas Knorr, Jürgen Dressel*, \\ Detlev Ganten**, and Johannes-Peter Stasch
}

\begin{abstract}
The cardiovascular consequences of mixed angiotensin converting enzyme and neutral endopeptidase (ACE/NEP) inhibition with alatriopril/alatrioprilat were compared with the consequences of endopeptidase (NEP) inhibition alone with (S)-thiorphan/ecadotril by determining the acute effects of the compounds on hemodynamic, hormonal, and renal parameters in hypertensive transgenic rats harboring an additional mouse renin gene (TGR(mRen2)27). Infusion of alatrioprilat and (S)-thiorphan in anesthetized TGR decreased blood pressure in a dose-dependent manner, but heart rate remained unchanged. The renal excretion of water, sodium, and cGMP also increased dose-dependently, with nearly the same maximal effects after infusion of (S)-thiorphan and alatrioprilat. At the end of infusion, plasma ANP and cGMP were elevated both after (S)-thiorphan and after alatrioprilat, whereas plasma renin activity increased only after alatrioprilat. The ACE inhibition effect was studied in ganglion-blocked rats receiving a continous infusion of angiotensin $I$. Alatrioprilat decreased the mean blood pressure dose-dependently, but about 30 times higher concentrations were needed to produce the same effects as the ACE inhibitor captopril. At a dose of $30 \mathrm{mg} / \mathrm{kg}$ p.o., ecadotril, the orally active prodrug of (S)-thiorphan, decreased the systolic blood pressure in conscious TGR by $22 \mathrm{mmHg}$ for $6 \mathrm{~h}$, whereas alatriopril (100 $\mathrm{mg} / \mathrm{kg} \mathrm{p.o.)} \mathrm{also} \mathrm{reduced} \mathrm{the} \mathrm{systolic} \mathrm{pressure} \mathrm{in} \mathrm{these} \mathrm{rats} \mathrm{with} \mathrm{a} \mathrm{maximal} \mathrm{reduction} \mathrm{of} 22 \mathrm{mmHg}$. In addition, ecadotril and alatriopril significantly increased the urinary excretion of sodium. In contrast, ACE inhibition with captopril decreased the excretion of sodium dose-dependently in conscious TGR. In conclusion, combined ACE/NEP inhibition produced a comparable lowering of blood pressure and improvement in renal function as those with NEP inhibition in TGR. Dual ACE/NEP inhibition may therefore be useful in cardiovascular conditions such as hypertension or heart failure. (Hypertens Res 1996; 19: 151-159)
\end{abstract}

Key Words: ecadotril, alatriopril, TGR(mRen2)27, ANP, hypertension

Two major hormonal peptide systems playing opposite roles in regulation of the electrolyte balance and blood pressure are activated in congestive heart failure. The first of these is the system of atrial natriuretic peptide (ANP), and the second is the reninangiotensin-aldosterone system (RAAS). ANP is secreted by atrial myocytes in response to an increase in intravascular volume and atrial stretching. This peptide, comprising 28 amino acids, is the first to be described among a family of hormones known to play an important part in the regulation of extracellular volume. ANP exerts a manifold influence in the kidney and the vascular system by effecting the excretion of sodium and water, lowering the blood pressure, and inhibiting the renin-angiotensinaldosterone system (1).
Enzymatic cleavage is an important degradative pathway of ANP. The neutral metalloendopeptidase (EC 3.4.24.11) (NEP) is a zinc-dependent cell surface enzyme widely distributed in the organism, including the brush border membranes of proximal renal tubules, the lungs, and the brain $(1,2)$. Cleavage of ANP by NEP destroys the essential ring structure, leading to biological inactivation of the hormone $(1,3)$. By inhibiting the inactivation of ANP, NEP inhibitors such as thiorphan, candoxatrilat, SQ 28,603, SQ 29,072, phosphoramidon, $\mathrm{SCH}$ 34,826 , and SCH 39,370 have been shown to increase the endogenous ANP levels and the sodium and water excretion in models such as DOCA/salt hypertensive rats and conscious and anesthetized normotensive and spontaneously hypertensive rats

From Bayer AG, Cardiovascular and Arteriosclerosis Research, *Institute of Chemistry, Wuppertal, Germany, and ** Max-Delbrück-Centre for Molecular Medicine, Berlin-Buch, Germany.

Address for Reprints: Johannes-Peter Stasch, Ph.D., Bayer AG, Cardiovascular and Arteriosclerosis Research, D-42096 Wuppertal, Germany.

Received September 7, 1995; accepted in revised form March 13, 1996. 
(3-13).

The RAAS exerts opposite effects to the ANP system and produces vasoconstriction and salt retention via the release of angiotensin II and aldosterone. Selective angiotensin converting enzyme (ACE) inhibitors are already in wide use, and have been shown to have highly benefical effects in the treatment of cardiovascular disorders such as hypertension and heart failure $(14,15)$. These drugs not only prevent the formation of angiotensin II and aldosterone secretion but also increase kinin levels, which also results in a lowering of blood pressure. Since both NEP and ACE are zinc-containing metallopeptidases closely involved in regulation of the two hormone systems, it makes sense to use dual inhibitors blocking both enzymes. However, most inhibitors available today are selective for either NEP or ACE: (S)-thiorphan has an affinity for NEP that is about 50 times higher than its affinity for ACE, whereas captopril inhibits ACE without any affinity for NEP (16). Recently, however, mixed inhibitors have been synthesized, which interact with both metallopeptidases at nanomolar concentrations in vitro (17-26). Substances such as alatriopril, glycopril, mixanpril, and MDL 100,240 have been shown to produce effects on blood pressure, electrolyte excretion, plasma ANP, and angiotensin in spontaneously hypertensive rats (SHR), renovascular hypertensive rats, and DOCA/salt hypertensive rats, consistent with inhibition of both ACE and NEP $(17,19-21,23,26)$. For the mixed inhibitor alatriopril, Bralet et al. (24) have shown that enhancement of ANP levels in the circulation by means of NEP inhibition enhances the capacity of ACE inhibitors to prevent cardiac hypertrophy, and they demonstrated the potential therapeutic value of mixed ACE/NEP inhibition in congestive heart failure.

The aim of the present study was to compare the effects of a mixed NEP/ACE inhibitor, alatrioprilat/ alatriopril (= prodrug), with those of a NEP inhibitor, (S)-thiorphan/ecadotril (= prodrug), on the basis of their renal, hormonal, and blood pressure effects in hypertensive rats carrying an additional mouse renin gene (TGR(m(Ren2)27)). As a result of their activated local reninangiotensin-aldosterone systems (RAAS), fulminant hypertension develops in TGR at the age of 5 weeks, with the systolic pressure more than 200 $\mathrm{mmHg}$. In contrast, the plasma renin levels are lower than those in normotensive Sprague Dawley rats. ANP, brain natriuretic peptide (BNP), cGMP, and plasma aldosterone are distinctly elevated in TGR $(27,28)$. The TGR is therefore an attractive model for investigations of NEP and ACE inhibitors: on the one hand, NEP inhibition has been shown to decrease blood pressure and increase the excretion of sodium by raising ANP and BNP plasma levels, and on the other hand, ACE inhibition reduces blood pressure and, in parallel, the renal excretion of water, sodium, and potassium $(28,29)$.

\section{Materials and Methods}

Substances

(S)-Thiorphan ((S)-3-mercapto-2-benzylpropanoylglycine) and alatrioprilat were synthesized by hydrolysis of ecadotril (trivial name, sinorphan) and alatriopril ((S)-N-[3,4-methylenedihydrooxyphenyl)2-(acethylthio)methyl-1-oxopropyl]-(S)-alanine benzylester), respectively. Ecadotril and alatropril were received from Bioprojet (France) and captopril from Sigma (Germany).

\section{In-Vivo Experiments}

The experiments were performed using TG (m(Ren2)27) rats (Zentralinstitut Bayer AG, Wuppertal, Germany) weighing 300-370 g. The rats were fasted but provided with drinking water from the evening before the start of the study.

Study I:

On the day of the study, the rats were anesthetized with thiopental "Lentia ${ }^{\circledR} "$ (Hormonchemie, Munich, Germany), $100 \mathrm{mg} / \mathrm{kg}$ i.p. A tracheotomy was performed, and catheters were inserted into the femoral artery for blood-pressure measurement (Gould P23 ID pressure transducer and Gould 2008s recorder) and the femoral vein for test-drug administration. Urine was collected through a catheter inserted into the bladder through a suprapubic incision. At the end of the operation, the rats received a starting injection of $5 \mathrm{ml}$ physiological saline $/ \mathrm{kg}$ followed by a continuous infusion of the same solution at $100 \mu \mathrm{l} / \mathrm{kg} / \mathrm{min}$ i.v. Their rectal temperature was maintained at $37.5 \pm 1^{\circ} \mathrm{C}$ with heat lamps. The rats were allowed an equilibration period of $1 \mathrm{~h}$ under these conditions before starting urine collection in weighed vials. After two control sampling periods of $20 \mathrm{~min}$ each, infusion of the substances dissolved in physiological saline was started. At the end of the experiment, blood samples were withdrawn from the femoral artery for the determination of plasma ANP, cGMP, renin activity, and aldosterone.

Study II:

The effects of acute administration of alatriopril, ecadotril, and captopril on renal excretion were investigated. The drugs were suspended in aqueous Tylose solution $(0.5 \%)$ containing $10 \%$ polyethylene glycol 400 and the administration volume was in each case $5 \mathrm{ml} / \mathrm{kg}$ p.o. For volume loading, the rats received $20 \mathrm{ml} / \mathrm{kg}$ of physiological $(0.9 \%)$ saline. Controls received Tylose solution $(0.5 \%)$ containing $10 \%$ polyethylene glycol 400 . For the determination of renal excretion, the rats were placed in metabolic cages and their urine was collected for a period of $6 \mathrm{~h}$.

\section{Study III:}

The blood-pressure-lowering effects of ecadotril and alatriopril were studied in conscious TG $(\mathrm{m}(\mathrm{Ren} 2) 27)$ rats. Ecadotril $(10$ and $30 \mathrm{mg} / \mathrm{kg})$ and alatriopril $(10,31.5$, and $100 \mathrm{mg} / \mathrm{kg})$ were administered orally, and the blood pressure was measured for a period of $6 \mathrm{~h}$ by the tail cuff method. 
Study IV:

To study the ACE inhibitory action of alatrioprilat and captopril, these substances were injected into ganglion-blocked anesthetized Sprague Dawley rats receiving a continous infusion of angiotensin I. The animals were anesthetized with thiopental "Lentia ${ }^{\circledR} "$ (Hormonchemie, Munich, Germany) at $100 \mathrm{mg} / \mathrm{kg}$ i.p.; a tracheotomy was performed, and catheters were inserted into the femoral artery for blood-pressure measurement (Gould P23 ID pressure transducer and 2008s recorder) and femoral vein for test-drug administration. Fifteen minutes after preparation of the animals, $5 \mathrm{mg} / \mathrm{kg}$ of pentolinum (Sigma, Germany) dissolved in $1 \mathrm{ml} / \mathrm{kg}$ of physiological saline $(0.9 \%)$ was injected i.v. After another $2 \mathrm{~min}$, an i.v. infusion of angiotensin I (Sigman, Germany) was started at $0.3 \mu \mathrm{g} / \mathrm{kg} / \mathrm{min}$, and the test substances were injected 8 min later.

Study $V$ :

In this part of the investigation we studied the effects of ecadotril (10 and $30 \mathrm{mg} / \mathrm{kg}$ p.o.), alatriopril (10 and $30 \mathrm{mg} / \mathrm{kg}$ p.o.), and captopril ( $3 \mathrm{mg} / \mathrm{kg}$ p.o.) on plasma neutral endopeptidase activity in conscious $\mathrm{TG}(\mathrm{m}(\operatorname{Ren} 2) 27)$ rats. Ecadotril, alatriopril, and captopril were suspended in aqueous Tylose solution $(0.5 \%)$ containing $10 \%$ polyethylene 400 . The administration volume was $5 \mathrm{ml} / \mathrm{kg}$ p.o. One hour after oral administration, blood was withdrawn from the tail vein and collected in lithium-heparin tubes. The samples were centrifuged, and the separated plasma was stored on ice until the time of the measurement.

\section{Measurement of Renal and Plasma Parameters}

Neutral endopeptidase activity: A fluorimetric twostep assay was used for the determination of NEP activity, as described previously (30). Succinyl-AlaAla-Pheamidomethylcoumarin (Bachem Pharma, Germany) served as a substrate. Blanks were obtained by adding $1 \mu \mathrm{M}$ thiorphan (Sigma, Germany) to the substrate solution from parallel incubations. The solution was incubated for half an hour at $37^{\circ} \mathrm{C}$, and the reaction was stopped by boiling at $56^{\circ} \mathrm{C}$. The fluorescence of the samples was measured with excitation at $367 \mathrm{~nm}$ and emission at $440 \mathrm{~nm}$.

Electrolyte excretion: The urine volume was determined gravimetrically and urinary flow rate was expressed in $\mathrm{ml} / \mathrm{kg} / \mathrm{h}$. Electrolyte concentrations were measured with the use of an electrolyte analyzer (Instrumentation Laboratory, USA). The excretion rates for sodium and potassium were expressed in $\mu \mathrm{mol} / \mathrm{min}$.

cGMP in plasma and urine: For the determination of cyclic GMP in plasma, an equal volume of $10 \%$ trichloroacetic acid was added to the sample. After $30 \mathrm{~min}$ of incubation, the tubes were centrifuged $\left(10 \mathrm{~min}, 4,930 \times \mathrm{g}, 4^{\circ} \mathrm{C}\right)$, and the supernatant was extracted with four portions of water-saturated ether to remove the acid and then lyophilized. The lyophilized product was redissolved in assay buffer, and cGMP was determined using a commercially available radioimmunoassay kit (IBL, Hamburg, Germany). The concentration of cyclic GMP in the urine was determined after dilution with ice-cold sodium acetate buffer $(0.05 \mathrm{M} ; \mathrm{pH} 6.2)$.

ANP in plasma: Plasma ANP was measured after extraction using $\mathrm{C}_{18}$-cartridges (Bond Elut ${ }^{\circledR}$ Analytichem, Frankfurt, Germany). For the determination of immunoreactive ANP in plasma, we used a commercially available RIA kit (Amersham, Germany).

Plasma renin activity $(P R A)$ : For the determination of PRA, the plasma was incubated with phenylmethylsulfonyl fluoride and the accumulation of angiotensin I was measured by radioimmunoassay (Sorin Biomedia, Saluggia, Italy).

Aldosterone in plasma: The aldosterone concentration in rat plasma was measured with the use of a commercially available radioimmunoassay kit (Sorin Biomedia, Saluggia, Italy).

\section{Statistics}

The differences were interpreted in an explorative way due to the limited number of animals per group. Therefore, no ANOVA was performed. Differences were checked for significance by Student's $t$-test at each point of time against control. All values in the tables and figures are expressed as the mean \pm SEM.

\section{Results}

Study I:

Table 1 and Figs. 1-3 summarize the renal, cardiovascular, and endocrine data for the mixed NEP/ACE inhibitor alatrioprilat, as compared with those for the selective NEP inhibitor (S)-thiorphan in anesthetized hypertensive TGR(m(Ren2)27). Both inhibitors were administered intravenously at doses of 30 and $100 \mu \mathrm{g} / \mathrm{kg} / \mathrm{min}$ for a period of 60 min. Alatrioprilat and (S)-thiorphan dose-dependently and significantly increased plasma ANP and cGMP at the end of the infusion period. The increase in plasma ANP and plasma cGMP was higher after (S)-thiorphan than after infusion of the mixed inhibitor alatrioprilat. Plasma renin activity (PRA) and plasma angiotensin I increased significantly after alatrioprilat in contrast to (S)-thiorphan. No significant effects on plasma aldosterone were observed after either (S)-thiorphan or alatrioprilat (Table 1). The mean arterial blood pressure was decreased significantly and dose-dependently by alatrioprilat and (S)-thiorphan, and maximal effects were obtained after $60 \mathrm{~min}$ of infusion $(-24 \mathrm{mmHg}$ and $-26 \mathrm{mmHg}$ for alatrioprilat, and $-13 \mathrm{mmHg}$ and $-20 \mathrm{mmHg}$ for (S)-thiorphan) (Fig. 1). There were no significant effects on heart rate (data not shown). As compared with vehicle-treated control rats, alatrioprilat and (S)-thiorphan increased the renal excretion of water, sodium, and cGMP dosedependently during the infusion of 30 and 100 $\mu \mathrm{g} / \mathrm{kg} / \mathrm{min}$. The effect of alatrioprilat on natriuresis tended to be stronger than that of (S)-thiorphan, but its effect on the urinary excretion of cGMP was smaller. Neither (S)-thiorphan nor alatrioprilat had any significant effect on the urinary excretion of potassium (Figs. 2, 3). 
Table 1. Effects of Alatrioprilat and (S)-Thiorphan on ANP, cGMP, Renin Activity (PRA), Angiotensin I (ANG I), and Aldosterone in the Plasma of TG(m(Ren2)27) Rats

\begin{tabular}{|c|c|c|c|c|c|}
\hline Substance (Dose) & ANP $(\mathrm{pg} / \mathrm{ml})$ & cGMP (pmol/ml) & PRA (ng/ml/h) & ANG I (ng/ml) & Aldosterone $(\mathrm{pg} / \mathrm{ml})$ \\
\hline Controls & $151 \pm 23(6)$ & $6.9 \pm 0.5(6)$ & $8.8 \pm 1.0(6)$ & $2.4 \pm 0.2(6)$ & $1259 \pm 79 \quad(6)$ \\
\hline $\begin{array}{l}\text { Alatrioprilat } \\
\qquad(30 \mu \mathrm{g} / \mathrm{kg} / \mathrm{min})\end{array}$ & $199 \pm 41(4)$ & $17.7 \pm 1.2(4)^{\#}$ & $10.7 \pm 1.7(6)$ & $2.5 \pm 0.3(6)$ & $994 \pm 143(6)$ \\
\hline $\begin{array}{l}\text { Alatrioprilat } \\
\qquad(100 \mu \mathrm{g} / \mathrm{kg} / \mathrm{min})\end{array}$ & $268 \pm 31(8) *$ & $13.8 \pm 1.5(8) \#$ & $19.3 \pm 4.5(7)^{* *}$ & $4.2 \pm 1.0(7)^{*}$ & $1252 \pm 130(7)$ \\
\hline $\begin{array}{l}\text { (S)-thiorphan } \\
(30 \mu \mathrm{g} / \mathrm{kg} / \mathrm{min})\end{array}$ & $303 \pm 19(6)^{\#}$ & $21.8 \pm 1.0(6)^{\#}$ & not measured & not measured & $802 \pm 109(4)$ \\
\hline $\begin{array}{l}\text { (S)-thiorphan } \\
(100 \mu \mathrm{g} / \mathrm{kg} / \mathrm{min})\end{array}$ & $348 \pm 41(6) * * *$ & $27.7 \pm 3.4(6)^{\#}$ & $11.8 \pm 1.5(6)$ & $3.2 \pm 0.4(6)$ & $997 \pm 118(8)$ \\
\hline
\end{tabular}

Values are presented as mean $\pm \operatorname{SEM}(\mathrm{n}) .{ }^{*} p<0.05,{ }^{* *} p<0.01,{ }^{* * *} p<0.005,{ }^{\#} p<0.001$. Comparison against untreated controls.

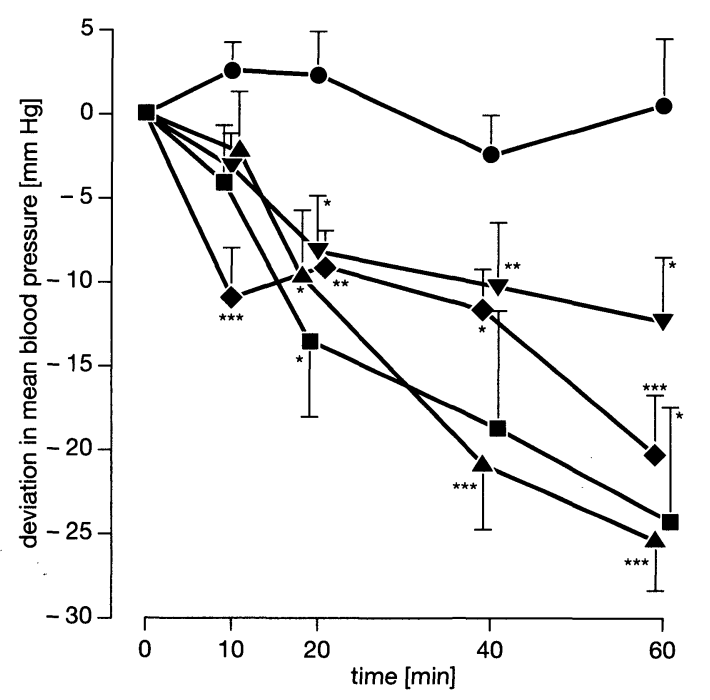

Fig. 1. Effects of alatrioprilat and (S)-thiorphan on the mean blood pressure in male anesthetized hypertensive $T G R(m(R e n 2) 27)$. The test compounds [alatrioprilat at 30 $\mu \mathrm{g} / \mathrm{kg} / \min (\boldsymbol{\square}, \mathrm{n}=6)$ and $100 \mu \mathrm{g} / \mathrm{kg} / \min (\boldsymbol{\Delta}, \mathrm{n}=8) ;(S)$ thiorphan at $30 \mu \mathrm{g} / \mathrm{kg} / \mathrm{min}(\nabla, \mathrm{n}=6)$ and $100 \mu \mathrm{g} / \mathrm{kg} / \mathrm{min}$ $(\diamond, \mathrm{n}=6)$; or vehicle $(\boldsymbol{O}, \mathrm{n}=6)$ were infused for a period of $60 \mathrm{~min}$. The basal levels of the mean blood pressure were respectively $143 \pm 13,154 \pm 5,145 \pm 8,160 \pm 7$, and $147 \pm 9 \mathrm{mmHg} .{ }^{*} \mathrm{p}<0.05,{ }^{* *} \mathrm{p}<0.01$, and ${ }^{* * *} \mathrm{p}<0.005$ vs. controls.

Study II:

The NEP inhibitor ecadotril and the combined NEP/ACE inhibitor alatriopril administered orally as a bolus to conscious TGR significantly increased the renal excretion of sodium and potassium and the sodium/potassium ratio (Table 2). In contrast, the selective ACE inhibitor captopril significantly suppressed natriuresis, diuresis, and kaliuresis in conscious TGR (Table 2).
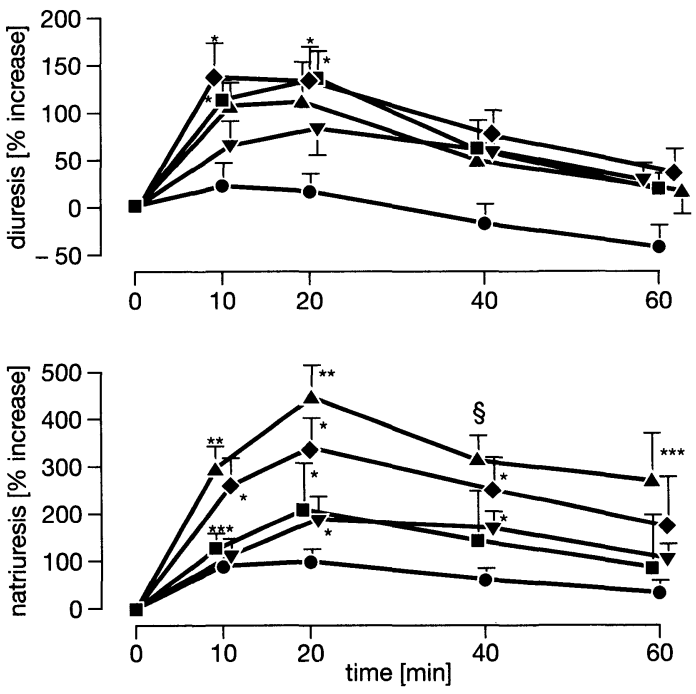

Fig. 2. Effects of alatrioprilat and (S)-thiorphan on diuresis and natriuresis in male anesthetized hypertensive TGR(m(Ren2)27). The test compounds [alatrioprilat at 30 $\mu \mathrm{g} / \mathrm{kg} / \min (\mathbf{\square}, \mathrm{n}=6)$ and $100 \mu \mathrm{g} / \mathrm{kg} / \min (\mathbf{\Delta}, \mathrm{n}=8) ;(S)$ thiorphan at $30 \mu \mathrm{g} / \mathrm{kg} / \mathrm{min}(\nabla, \mathrm{n}=6)$ and $100 \mu \mathrm{g} / \mathrm{kg} / \mathrm{min}$ $(\diamond, \mathrm{n}=6)$; or vehicle $(\bigcirc, \mathrm{n}=6)$ were infused for a period of $60 \mathrm{~min}$. The basal levels of diuresis $[\mathrm{ml} / \mathrm{kg} / \mathrm{h}]$ were respectively $2.87 \pm 0.86,2.57 \pm 0.614 .59 \pm 0.72,4.13 \pm 0.99$, and $6.54 \pm 3.49$, and those of natriuresis [umol/min] respectively $1.59 \pm 0.31,1.20 \pm 0.41,2.41 \pm 0.85,1.23 \pm 0.32$, and $2.22 \pm 1.20$. $* \mathrm{p}<0.05, * * \mathrm{p}<0.01,{ }^{* * *} \mathrm{p}<0.005$, and $\S \mathrm{p}<0.001$ vs. controls.

\section{Study III:}

In conscious TGR, ecadotril, the orally active prodrug of (S)-thiorphan, decreased the systolic blood pressure dose-dependently, with a maximal effect of $-13 \mathrm{mmHg}$ after an oral dose of $10 \mathrm{mg} / \mathrm{kg}$ p.o. and a maximal effect of $-23 \mathrm{mmHg}$ after $30 \mathrm{mg} / \mathrm{kg}$ (Fig. 4). The antihypertensive effect of $30 \mathrm{mg} / \mathrm{kg}$ p.o. ecadotril was still present after $6 \mathrm{~h}$. The orally 
Table 2. Effects of Oral Administration of Ecadotril, Alatriopril, and Captopril on Diuresis, Natriuresis, Kaliuresis, and the Sodium/Potassium Ratio in Male Conscious TG(m(Ren2)27) Rats.

\begin{tabular}{lccccc}
\hline Substance & Dose & $\begin{array}{c}\text { Diuresis } \\
(\mathrm{ml} / \mathrm{kg} / \mathrm{h})\end{array}$ & $\begin{array}{l}\text { Natriuresis } \\
(\mu \mathrm{mol} / \mathrm{kg} / \mathrm{h})\end{array}$ & $\begin{array}{c}\text { Kaliuresis } \\
(\mu \mathrm{mol} / \mathrm{kg} / \mathrm{h})\end{array}$ & $\mathrm{Na} / \mathrm{K} \mathrm{ratio}$ \\
\hline Controls & & $4.7 \pm 0.3(6)$ & $254.1 \pm 26.4(6)$ & $141.8 \pm 10.8(6)$ & $1.8 \pm 0.1(6)$ \\
Ecadotril & $1 \mathrm{mg} / \mathrm{kg}$ & $5.2 \pm 0.6(8)$ & $335.1 \pm 55.2(8)$ & $202.1 \pm 30.8(8)$ & $1.7 \pm 0.3(8)$ \\
& $3 \mathrm{mg} / \mathrm{kg}$ & $4.5 \pm 0.5(8)$ & $376.3 \pm 31.1(8)^{*}$ & $190.1 \pm 24.6(8)$ & $2.1 \pm 0.2(8)$ \\
& $10 \mathrm{mg} / \mathrm{kg}$ & $4.8 \pm 0.5(8)$ & $468.8 \pm 48.2(8)^{* *}$ & $178.7 \pm 22.8(8)$ & $2.7 \pm 0.2(8)^{*}$ \\
& $30 \mathrm{mg} / \mathrm{kg}$ & $5.1 \pm 0.3(8)$ & $465.0 \pm 59.1(8)^{*}$ & $205.4 \pm 14.3(8)^{*}$ & $2.3 \pm 0.2(8)$ \\
Alatriopril & $1 \mathrm{mg} / \mathrm{kg}$ & $4.9 \pm 0.4(6)$ & $402.6 \pm 55.6(6)^{*}$ & $174.0 \pm 22.8(6)$ & $2.4 \pm 0.3(6)$ \\
& $3 \mathrm{mg} / \mathrm{kg}$ & $5.6 \pm 0.5(6)$ & $461.1 \pm 83.0(6)^{*}$ & $196.9 \pm 22.0(6)$ & $2.3 \pm 0.2(6)$ \\
& $10 \mathrm{mg} / \mathrm{kg}$ & $4.8 \pm 0.7(6)$ & $394.2 \pm 58.7(6)$ & $150.3 \pm 21.5(6)$ & $2.7 \pm 0.3(6)^{*}$ \\
& $0.1 \mathrm{mg} / \mathrm{kg}$ & $2.6 \pm 0.4(8)^{\#}$ & $131.2 \pm 40.0(8)^{* *}$ & $179.5 \pm 31.1(8)$ & $0.7 \pm 0.2(8)^{\#}$ \\
& $0.3 \mathrm{mg} / \mathrm{kg}$ & $1.4 \pm 0.2(8)^{\#}$ & $28.8 \pm 16.8(8)^{\#}$ & $74.5 \pm 19.0(8)^{* *}$ & $0.3 \pm 0.1(8)^{\#}$ \\
& $1.0 \mathrm{mg} / \mathrm{kg}$ & $1.3 \pm 0.1(8)^{\#}$ & $31.9 \pm 10.8(8)^{\#}$ & $107.9 \pm 19.8(8)$ & $0.3 \pm 0.1(8)^{\#}$ \\
\hline
\end{tabular}

Values are presented as mean \pm SEM. ${ }^{*} p<0.05,{ }^{* *} p<0.01,{ }^{\#} p<0.001$. Comparison against untreated controls. The collection period was $6 \mathrm{~h}$.
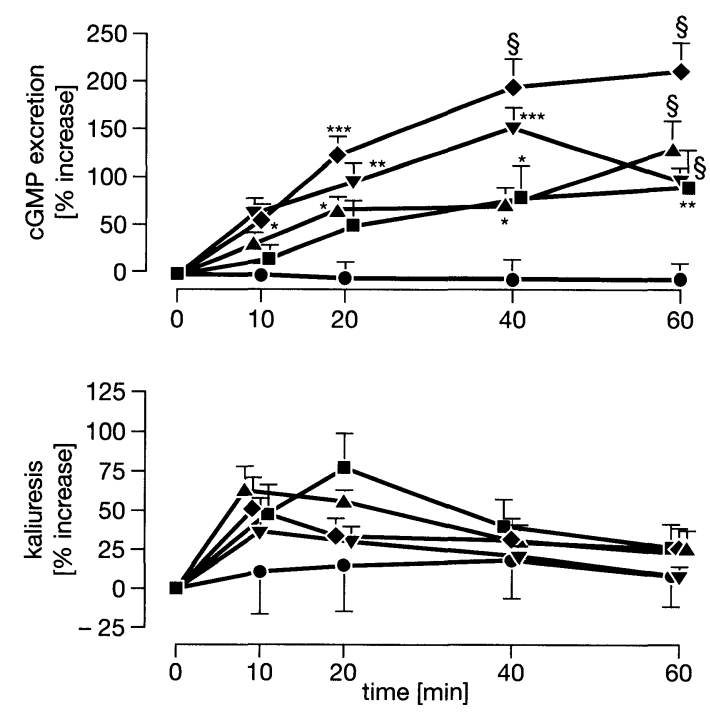

Fig. 3. Effects of alatrioprilat and (S)-thiorphan on cGMP excretion and kaliuresis in male anesthetized hypertensive TGR(m(Ren2)27). The test compounds [alatrioprilat at $30 \mu \mathrm{g} / \mathrm{kg} / \mathrm{min}(\mathbf{\square}, \mathrm{n}=6)$ and $100 \mu \mathrm{g} / \mathrm{kg} / \mathrm{min}(\mathbf{\Delta}$, $\mathrm{n}=8) ;(S)$-thiorphan at $30 \mu \mathrm{g} / \mathrm{kg} / \mathrm{min}(\boldsymbol{\nabla}, \mathrm{n}=6)$ and 100 $\mu \mathrm{g} / \mathrm{kg} / \min (\diamond, \mathrm{n}=6)$; or vehicle $(\boldsymbol{O}, \mathrm{n}=6)$ were infused for a period of $60 \mathrm{~min}$. The basal levels of urinary excretion of cGMP [nmol/ $\mathrm{kg} / \mathrm{h}]$ were respectively 12,913 \pm $5,223,5,746 \pm 436,13,833 \pm 3,357,10,605 \pm 1,209$, and $10,424 \pm 2,323$, and those of kaliuresis [ $\mathrm{mol} / \mathrm{min}]$ respectively $1.64 \pm 0.13,1.85 \pm 0.17,1.92 \pm 0.26,2.14 \pm 0.17$, and $1.73 \pm 0.46 .{ }^{*} \mathrm{p}<0.05,{ }^{* *} \mathrm{p}<0.01,{ }^{* * *} \mathrm{p}<0.005$, and ${ }^{\mathrm{s}}<$ 0.001 vs. controls.

active prodrug of alatrioprilat, alatriopril, lowered systolic blood pressure dose-dependently in TGR, but to achieve a similar decrease in systolic pressure as after ecadotril an approximately 3 times greater dose was needed $(-23 \mathrm{mmHg}$ after administration of $100 \mathrm{mg} / \mathrm{kg}$ p.o.). In contrast to ecadotril, however, the systolic blood pressure returned to baseline

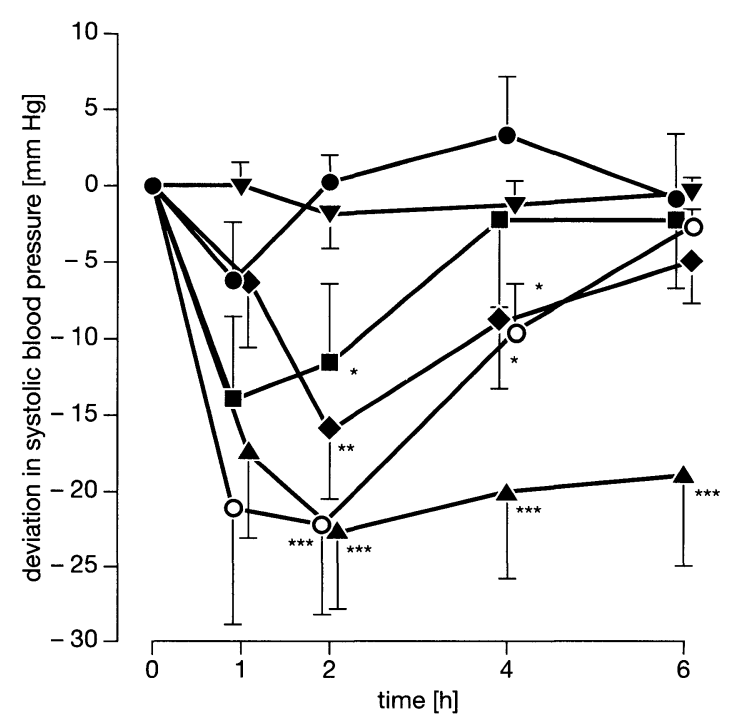

Fig. 4. Effects of ecadotril (10 and $30 \mathrm{mg} / \mathrm{kg}$ p.o.) and alatriopril $(10,31.5$, and $100 \mathrm{mg} / \mathrm{kg} \mathrm{p.o.)} \mathrm{on} \mathrm{the} \mathrm{systolic}$ blood pressure in conscious TGR. Alatriopril $10 \mathrm{mg} / \mathrm{kg}$ p.o. $(\nabla, \mathrm{n}=5), 31.5 \mathrm{mg} / \mathrm{kg}$ p.o. $(\diamond, \mathrm{n}=5)$, and 100 $\mathrm{mg} / \mathrm{kg}$ p.o. $(\mathrm{O}, \mathrm{n}=5)$; ecadotril $10 \mathrm{mg} / \mathrm{kg}$ p.o. $(\mathbf{\square}, \mathrm{n}=11)$ and $30 \mathrm{mg} / \mathrm{kg}$ p.o. $(\mathbf{\Delta}, \mathrm{n}=12)$; or vehicle $(\mathbf{0}, \mathrm{n}=11)$ were administered. The basal levels of the mean blood pressure were $182 \pm 8 \mathrm{mmHg} .{ }^{*} \mathrm{p}<0.05,{ }^{* *} \mathrm{p}<0.01,{ }^{* * *} \mathrm{p}<0.005$ vs. controls.

after $6 \mathrm{~h}$ in the TGR treated with alatriopril (Fig. $4)$.

Study IV:

In ganglion-blocked anesthetized rats, infusion of angiotensin I leads to an increase in blood pressure. In this animal model, used for the investigation of $\mathrm{ACE}$ inhibition in vivo, the mixed $\mathrm{ACE} / \mathrm{NEP}$ inhibitor alatrioprilat decreased the mean arterial pressure dose-dependently. Captopril also decreased 


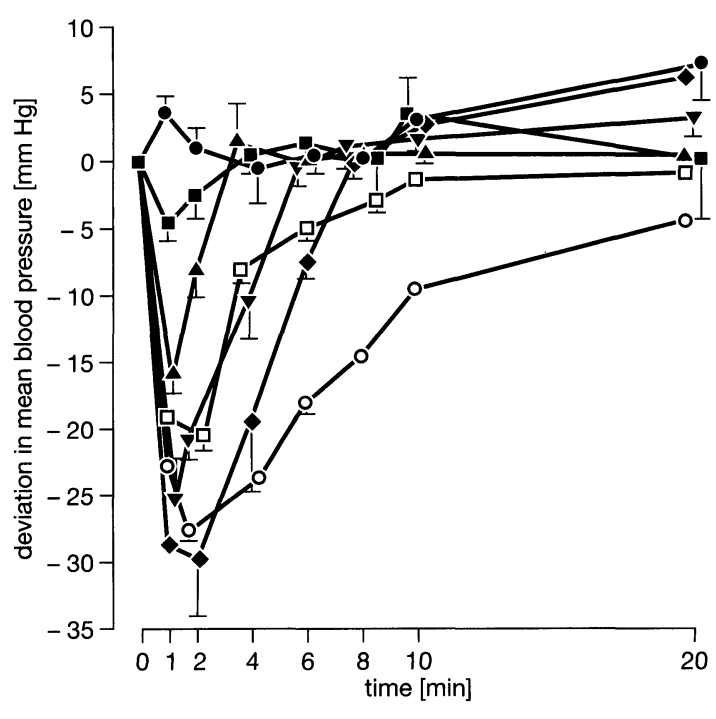

Fig. 5. Effects of alatrioprilat and captopril on blood pressure in ganglion-blocked rats receiving continous angiotensin I infusion $(0.3 \mu \mathrm{g} / \mathrm{kg} / \mathrm{min}$ i.v.). The test compounds [alatrioprilat at $30 \mu \mathrm{g} / \mathrm{kg}$ (口), $100 \mu \mathrm{g} / \mathrm{kg}(\mathbf{\Delta}), 300$ $\mu \mathrm{g} / \mathrm{kg}(\boldsymbol{\nabla})$ and $1000 \mu \mathrm{g} / \mathrm{kg}(\diamond)$; captopril at $10 \mu \mathrm{g} / \mathrm{kg}(\square)$ and $30 \mu \mathrm{g} / \mathrm{kg}(\bigcirc)$; or vehicle (O)] were infused as a bolus $(\mathrm{n}=2)$. The basal values of the mean blood pressure were respectively $116 \pm 7,135 \pm 21,131 \pm 16,130 \pm 10,141 \pm 3$, $165 \pm 9$, and $119 \pm 12 \mathrm{mmHg}$. $* \mathrm{p}<0.05, * * \mathrm{p}<0.01, * * * \mathrm{p}$ $<0.005, \S \mathrm{p}<0.001$, as compared with values in untreated controls.

the mean arterial pressure dose-dependently, but about 30 times lower concentrations of captopril were sufficient to produce the same blood-pressurelowering effects as alatrioprilat (Fig 5). However, the duration of the effect on blood pressure after bolus injection of the substances was very short. (S)-Thiorphan had no effect on blood pressure in this model (data not shown).

\section{Study $V$ :}

After oral administration of the prodrugs ecadotril and alatriopril (10 and $30 \mathrm{mg} / \mathrm{kg}$ p.o.), the neutral endopeptidase activity in plasma was inhibited dosedependently $1 \mathrm{~h}$ after administration. Captopril had no effect on the plasma NEP activity (Table 3 ).

\section{Discussion}

The aim of the present study was to compare the cardiovascular, hormonal, and renal effects of the mixed ACE/NEP inhibitor alatrioprilat or its orally active prodrug alatriopril with the corresponding effects of the selective NEP inhibitor (S)-thiorphan or its orally active prodrug ecadotril in hypertensive TGR harboring an additional mouse Ren-2 renin gene $(\operatorname{TGR}(m(\operatorname{Ren} 2) 27))$. The TGR are not only used for the investigation of substances that interact with the renin-angiotensin-aldosterone system (RAAS), but also posses an activated ANP system, which makes them attractive for the investigation of
Table 3. Effects of Ecadotril, Alatriopril, and Captopril on Plasma Neutral Endopeptidase Activity in TG (m(Ren2)27) Rats 1 h after Oral Administration

\begin{tabular}{lccc}
\hline Substance & Dose & NEP activity $(\mathrm{pmol} / \mathrm{ml} / \mathrm{min})$ \\
\hline Controls & & $37.3 \pm 3.5$ & $(5)$ \\
Ecadotril & $10 \mathrm{mg} / \mathrm{kg}$ p.o. & $11.0 \pm 3.4^{* * *}(4)$ \\
Ecadotril & $30 \mathrm{mg} / \mathrm{kg}$ p.o. & $8.0 \pm 0.8^{* * *}$ & $(5)$ \\
Alatriopril & $10 \mathrm{mg} / \mathrm{kg}$ p.o. & $10.0 \pm 3.6^{* * *}$ & $(5)$ \\
Alatriopril & $30 \mathrm{mg} / \mathrm{kg}$ p.o. & $5.7 \pm 0.8^{* * *}$ & $(5)$ \\
Captopril & $3 \mathrm{mg} / \mathrm{kg}$ p.o. & $45.2 \pm 4.7$ & $(5)$ \\
\hline
\end{tabular}

Values are presented as mean $\pm \operatorname{SEM}(\mathrm{n}){ }^{* * *} p<0.005$ Comparison against untreated controls.

compounds that interact with the natriuretic peptides system (27-29). In addition, we showed that neutral endopeptidase (NEP) activity is significantly higher in hypertensive transgenic animals than in normotensive controls (28). These findings suggest that NEP inhibitors such as (S)-thiorphan or the mixed ACE/NEP inhibitor alatrioprilat are more effective in animal models with elevated NEP activity, than in models with no elevation of NEP activity.

Alatrioprilat inhibits both NEP $\left(\mathrm{IC}_{50}=7 \times 10^{-9}\right.$ $\mathrm{mol} / \mathrm{l})$ and $\mathrm{ACE}\left(\mathrm{IC}_{50}=1 \times 10^{-8} \mathrm{~mol} / \mathrm{l}\right)$ whereas $(\mathrm{S})$ thiorphan is selective for NEP $\left(\mathrm{IC}_{50}=2 \times 10^{-9}\right.$ $\mathrm{mol} / \mathrm{l})$. Our results indicate that both (S)-thiorphan and alatrioprilat increase plasma atrial natriuretic peptide (ANP) and its second messenger cyclic GMP after infusion in TGR. However, the effects of the NEP inhibitor (S)-thiorphan on plasma ANP and cGMP are stronger than the effects of the same dosage of the NEP/ACE inhibitor alatrioprilat. Many studies have shown that the renal and bloodpressure-lowering effects of NEP inhibitors are intensified, even when plasma ANP levels are already elevated, by conditions such as those of animal models of hypertension and heart failure and by conditions of volume expansion $(4,9,28,31)$. Furthermore, NEP inhibitors have been shown to increase plasma ANP and cGMP (5, 7, 8, 10-13). Recently, we reported that the oral administration of ecadotril to TGR with an activated natriuretic peptide system induced further increases in plasma ANP, plasma brain natriuretic peptide (BNP), and plasma and urinary cGMP. In contrast, the effects on ANP, BNP, and cGMP were much smaller in normotensive control rats, with no activated natriuretic peptide system (28). This was why TGR were used in our study. In addition, chronic treatment with ecadotril (30 $\mathrm{mg} / \mathrm{kg}$ p.o. bid) in TGR (28) and in stroke-prone spontaneously hypertensive rats (32) prevented the development of hypertension and cardiac hypertrophy, apparently by inhibition of NEP. Interestingly, in a chronic (4 wk) study in rats with myocardial infarction alatriopril at $100 \mathrm{mg} / \mathrm{kg}$ p.o. did not significantly increase plasma ANP as compared with ligated control animals. However, in these ligated rats the plasma ANP was 2.5 times higher after alatriopril than after captopril 
(10 mg/kg p.o.) (24). In normotensive anesthetized Wistar rats alatriopril has been shown to increase the urinary excretion of cGMP, which is a marker for ANP involvement (17). Several studies have shown that treatment with selective ACE inhibitors such as captopril reduces plasma ANP by a decrease in blood pressure $(24,33,34)$, so that one possible explanation for the lower plasma ANP in TGR treated with alatrioprilat as compared with those treated with (S)-thiorphan may be the ACEinhibitory-action component of alatrioprilat.

Our study in TGR has shown that both (S)-thiorphan and alatrioprilat decreased blood pressure dose-dependently, although the effect was stronger after alatrioprilat than after (S)-thiorphan. In contrast, when the prodrugs were used in conscious TGR, the antihypertensive effect of ecadotril was stonger and more prolonged than that of alatriopril in TGR. The reason for the different antihypertensive effects of pure NEP inhibitors and dual ACE/NEP inhibitors is yet not clear. On the one hand, it is well known that anesthesia activates the renin-angiotensin system and, consequently, anesthetized animals become more sensitive to the blood-pressure-lowering action of ACE inhibitors than conscious TGR. Furthermore, pharmacokinetic differences between the prodrugs could also not be excluded. In accord with our results, Seymour et al. (35) and Pham et al. (9, 20, 36) reported that the blood-pressure-lowering effect after the infusion of a mixed inhibitor or of a combination of captopril and retrothiorphan in anesthetized rats was greater than the response to any of the inhibitors given alone. Similar results were obtained by Roques et al. $(37,38)$ in anesthetized SHR: the mixed inhibitor mixanpril had a greater effect in lowering blood pressure than either the NEP inhibitor retrothiorphan or the ACE inhibitor enalapril alone. These studies suggest that parallel inhibition of ACE and NEP may be more advantagous than pure ACE or NEP inhibition in lowering blood pressure in hypertensive SHR, where blood pressure is genetically determined. In contrast, in TG rats, the bloodpressure-lowering effect was comparable for ecadotril and alatriopril.

In the present study, administration of either alatrioprilat or (S)-thiorphan increased the urinary excretion of water, sodium, and cGMP dose-dependently, with only slight effects on the excretion of potassium. The effect on cGMP excretion was slightly more pronounced after (S)-thiorphan, while the excretion of sodium was comparable for the treated animals. In addition, previous studies have shown that the effect of NEP inhibition with ecadotril on renal excretion of water and sodium is greater in TGR than in normotensive Sprague Dawley controls, suggesting that NEP inhibitors are more effective in the presence of elevated plasma ANP levels (28). Similar results have been obtained after infusion of (S)-thiorphan, the active metabolite of ecadotril, in anesthetized dogs. The effects of (S)thiorphan on natriuresis, diuresis, and urinary ANP are more pronounced under conditions of elevated plasma ANP, induced by a blockade of the ANP clearance receptors, than under normal conditions (39). In the aorto-venocaval fistula (AVF) rat model of heart failure, in which the plasma ANP levels are increased by a factor of 3 or 4 as compared with sham-operated rats, ecadotril also significantly increased the reduced renal excretion of sodium after a single oral dose (40). In addition, in patients with chronic heart failure and renal insufficiency, similarly characterized by elevated plasma ANP, renal excretion of sodium but not of potassium increased after a single dose of ecadotril (41).

Regarding renal parameters, we did not observe any stronger effects of alatrioprilat compared with (S)-thiorphan in the anesthetized TGR. This could be related to the greater decrease in blood pressure in the alatrioprilat-treated animals. In conscious TGR, the urinary excretion of sodium and water and the increase in the sodium/potassium ratio seem to depend on the NEP inhibition by ecadotril and alatriopril and not to be influenced by the ACE inhibitory component of alatrioprilat. It has been suggested that bradykinin is involved in the renal effects of NEP inhibition, but data obtained with bradykinin antagonists are still conflicting (42-44). In a recent paper (29), we reported the profound antinatriuresis and antidiuresis caused by captopril and the angiotensin II antagonist losartan in conscious TGR, effects that are associated with inhibition of the renin-angiotensin system in these rats. It is possible that the reduction in both the systemic blood pressure and renoactive ANP caused by captopril in TGR was responsible for the observed reduction in renal sodium excretion. Taken together, these results show that ecadotril and alatriopril exert their renal and hemodynamic effects by inhibition of NEP, and that the ACE-inhibitory-action component of alatriopril obviously did not influence these effects in the TGR. Subsequent to studies with mixed ACE/NEP inhibitors, French et al. (23) reported that MDL 100,240 administered to normotensive Sprague Dawley rats significantly enhanced the renal and hemodynamic effects of an ANP infusion. Similarly, in hypertensive conscious SHR infusion of the mixed ANP/ACE inhibitor mixanpril $(18,19)$ resulted in a substantial increase in natriuresis and a reduction in blood pressure, but admittedly the dosage was very high $(25 \mathrm{mg} / \mathrm{kg}$ i.v. bolus $+25 \mathrm{mg} / \mathrm{kg} / \mathrm{h}$ i.v. .).

To study ACE inhibitory activity in vivo, we tested alatrioprilat in the ganglion-blocked rat after a continuous infusion of angiotensin I and compared the effects with those of captopril alone. About 30-fold higher concentrations of alatrioprilat were needed to produce the same decrease in blood pressure as captopril. As expected, (S)-thiorphan had no effect on blood pressure in this model. After infusion of alatrioprilat, the plasma renin activity in TGR is nearly doubled, probably in connection with the weak ACE inhibition component of this compound (20). In contrast, after infusion of (S)-thiorphan PRA is not significantly elevated, despite the natriuretic activity, probably because of the RAAS-suppressing action of ANP. In an earlier study in hypertensive TGR, acute oral administra- 
tion of ecadotril caused a slight increase in plasma renin activity as compared with normotensive control rats, probably as a result of the acute excretion of sodium (28). In clinical studies, the PRA remained unchanged after ecadotril treatmant in healthy normotensive subjects and in patients with chronic renal insufficiency and decreased slightly in patients with congestive heart failure $(41,45)$. A slight but not significant decrease in the plasma aldosterone was observed in our study after both substances.

In conclusion, simultaneous inhibition of $\mathrm{ACE}$ and NEP may result in several potentially useful therapeutic effects. These effects largely reflect the interplay of these functionally opposed hormonal systems at various physiological levels. The diuretic, natriuretic, vasorelaxant, and renin- and aldosterone-supressing effects of endogenous ANP can be regarded as beneficial in cardiovascular conditions such as chronic heart failure and essential hypertension. It can therefore be concluded from these investigations in TGR that inhibition of both NEP and ACE may be a useful therapeutic strategy in cardiovascular diseases such as hypertension or heart failure.

\section{Acknowledgements}

The authors with to thank Mrs. C. Diederichs, R. Hartkopf, P. Heinz, Mrs. Y. Keim, S. Knipping and R. Köster for outstanding technical assistance.

\section{References}

1. Ruskoaho H: Atrial natriuretic peptide: synthesis, release, and metabolism. Pharacol Rev 1992; 44: 479602.

2. Olins GM, Spear KL, Siegel NR, Zurcher-Neely HA: Inactivation of atrial natriuretic factor by the renal brush border. Biochim Biophys Acta 1987; 901: 97-100.

3. Olins GM, Krieter PA, Trapani AJ, Spear KL, Bovy BR: Specific inhibitors of endopeptidase 24.11 inhibit the metabolism of atrial natriuretic peptides in vitro and in vivo. Mol Cell Endocrinol 1989; 61: 201-208.

4. Sybertz EJ, Chiu PJS, Vemulapalli S, et al: SCH 39370 , a neutral metalloendopeptidase inhibitor, potentiates biological responses to atrial nautriuretic factor and lowers blood pressure in desoxycorticosterone acetate-sodium hypertensive rats. $J$ Pharmacol Exp Ther 1989; 250: 624-631.

5. Koepke JP, Tylor LD, Mehta PP, et al: Atriopeptin regulation and renal function in conscious spontaneously hypertensive rats. Am J Hypertens 1990; 3: 622-627.

6. Vemulapalli S, Chiu PJS, Brown A, Griscti K, Sybertz EJ: The blood pressure and renal responses to $\mathrm{SCH} 34826$, a neutral metalloendopeptidase inhibitor, and C-ANF(4-23) in DOCA-salt hypertensive rats. Life Sci 1991; 49: 383-391.

7. Seymour AA, Norman JA, Asaad MM, et al: Possible regulation of atrial natriuretic factor by neutral endopeptidase 24.11 and clearance receptors. J Pharmacol Exp Ther 1991; 256: 1002-1009.

8. Danilewiez JC, Barclay PL, Barnish IT, et al: UK69,578, a novel inhibitor of E.C. 3.4.24.11 which increases endogenous ANF levels and its natriuretic and diuretic response. Biochem Biophys Res Commun 1989; 164: 58-65.

9. Pham I, El Amrani AIK, Fournie-Zaluski MC, Corvol P, Roques BP, Michel JB: Effects of the selective neutral endopeptidase inhibitor, retrothiorphan, on renal function and blood pressure in conscious normotensive Wistar and hypertensive DOCA-salt rats. J Cardiovasc Pharmacol 1992; 20: 847-857.

10. Schwartz JC, Gros C, Lecomte JM, Bralet J: Enkephalinase (EC 3.4.24.11) inhibitors. Protection of endogenous ANF against inactivation and potential the rapeutic applications. Life Sci 1990; 47: 12791297.

11. Seymour AA, Swerdel JN, Fennell SA, Druckman P, Neubeck R, Delaney NG: Potentiation of the depressor responses to atrial natriuretic peptides in conscious SHR by an inhibitor of neutral endopeptidase. J Cardiovasc Pharmacol 1989; 14: 194-204.

12. Wilkins MR, Settle SL, Stockmann PT, Needleman P: Maximizing the natriuretic effect of endogenous atriopeptin in a rat model of heart failure. Proc Nat Acad Sci USA 1990; 87: 6465-6469.

13. Seymour AA, Norman JA, Assad MM, et al: Renal and depressor effects of SQ 29,072 , a neutral endopeptidase inhibitor, in conscious hypertensive rats. $J$ Cardiovasc Pharmacol 1990; 16: 163-172.

14. Gavras H, Gavras I: Cardioprotective potential of angiotensin converting enzyme inhibitors. J Hypertens 1991; 1: 385-392.

15. Laragh J: New angiotensin converting enzyme inhibitors. Am J Hypertens 1990; 3: 257S-265S.

16. Waeber B, Nussberger J, Brunner H: Pathology, diagnosis and management, in Laragh $\mathrm{JH}$, Brenner BM (eds): Hypertension. New York, Raven Press, 1990, 2, pp2209-2232.

17. Gros C, Noel N, Souque A, et al: Mixed inhibitors of angiotensin-converting enzyme (EC 3.4.15.1) and enkephalinase (EC 3.4.24.11): rational design, properties, and potential cardiovascular applications of glycopril and alatriopil. Proc Natl Acad Sci USA 1991; 88: 4210-4214.

18. Fournie-Zaluski MC, Coric P, Turcaud S, et al: New dual inhibitors of neutral endopeptidase and angiotension-converting enzyme: rational design, bioavailability, and pharmacological responses in experimental hypertension. J Med Chem 1994; 37: 1070-1083.

19. Fournie-Zaluski MC, Gonzalez W, Turcaud S, Pham I, Roques BP, Michel JB: Dual inhibition of angiotensin-converting enzyme and neutral endopeptidase by the orally active inhibitor mixanpril: a potential therapeutic approach in hypertension. Proc Natl Acad Sci 1994; 91: 4072-4076.

20. Pham I, Gonzales W, El Amrani AIK, et al: Effects of converting enzyme inhibitor and neutral endopeptidase inhibitor on blood pressure and renal function in experimental hypertension. J Pharmacol Exp Ther 1993; 265: 1339-1347.

21. Flynn GA, Beight DW, Mehidi S, et al: Application of a conformationally restricted Phe-Leu dipeptide mimetic to the design of a combined inhibitor of angiotensin I-converting enzyme and neutral endopeptidase 24.11. J Med Chem 1993; 36: 2420-2423.

22. Stanton JL, Sperbeck DM, Trapani AJ, et al: Heterocyclic lactam derivatives as dual angiotensin converting enzyme and neutral endopeptidase 24.11 inhibitors. J Med Chem 1993; 36: 3829-3833.

23. French JF, Flynn GA, Giroux EL, et al: Characterization of a dual inhibitor of angiotensin I-converting enzyme and neutral endopeptidase. J Pharmacol Exp Ther 1994; 268: 180-186. 
24. Bralet J, Marie C, Mossiat C, Lecomte JM, Gros C, Schwartz JC: Effects of alatriopril, a mixed inhibitor of atriopeptidase and angiotensin I-converting enzyme, on cardiac hypertrophy and hormonal responses in rats with myocardial infarction. Comparison with captopril. J Pharmacol Exp Ther 1994; 270: 8-14.

25. Richard V, Lecomte JM, Thuillez C: Effets hemodynamiques systemiques et regionaux d'un nouvel inhibiteur mixte de l'enzyme de conversion de l'angiotensine et de l'endopeptidase neutre, l'alatriopril, chez le chien. Arch Mal Coeur 1993; 86: 1275-1279.

26. Vera WG, Fournie-Zaluski MC, Pham I, Laboulandine I, Roques BP, Michel JB: Hypotensive and natriuretic effects of $\mathrm{RB} 105$, a new dual inhibitor of angiotensin converting enzyme and neutral endopeptidase in hypertensive rats. $J$ Pharmacol Exp Ther 1995; 272: 341-351.

27. Bachmann S, Peters J, Engler E, Ganten D, Mullins $\mathrm{J}$ : Transgenic rats carrying the mouse renin gene: morphological characterization of a low-renin hypertension model. Kidney Int 1992; 41: 24-36.

28. Stasch JP, Hirth-Dietrich C, Ganten D, Wegner M: Cardiorenal consequences of neutral endopeptidase inhibition in transgenic rats with an extra renin gene. Am J Hypertens 1996; 9 (in press).

29. Hirth-Dietrich C, Stasch JP, Ganten D, Luft FC: Renal effects of captopril and nitrendipine in transgenic rats with an extra renin gene. Hypertension 1994; 23: 626-631.

30. Yandle T, Richards M, Smith M, Charles C, Livesey J, Espiner E: Assay of endopeptidase-24.11 activity in plasma applied to in vivo studies of endopeptidase inhibitors. Clin Chem 1992; 38: 1785-1791.

31. Hirata Y, Suzuki E, Hayakawa H, et al: Mechanisms of the natriuretic effects of neutral endopeptidase inhibition in Dahl salt-sensitive and salt-resistant rats. $J$ Cardiovasc Pharmacol 1994; 23: 283-290.

32. Stasch JP, Knorr A, Wegner M, Hirth-Dietrich C: Prolonged inhibition of neutral endopeptidase 24.11 by sinorphan in SHR-SP. Hypertens Res 1995; 18: 1128-1134.

33. Crozier IG, Nicholls MG, Ikram H, Espiner EA, Yandle TG: Atrial natriuretic peptide levels in congestive heart failure in man before and during converting enzyme inhibition. Clin Exp Pharmacol Physiol 1989; 16: 417-424.

34. Michel JB, Lattion AL, Salzmann JL, et al: Hormonal and cardiac effect of converting enzyme inhibition in rat myocardial infarction. Circ Res 1988; 62: 641-650.

35. Seymour AA, Swerdel JN, Abboa-Offei B: Antihypertensive activity during inhibition of neutral endopeptidase and angiotensin converting enzyme. $J$ Cardiovasc Pharmacol 1991; 17 456-465.

36. Pham I, Levy B, Fournie-Zaluski, Poitevin P, Roques BP, Michel JB: Acute hemodynamic effects of combined inhibition of neutral endopeptidase and angiotensin converting enzyme in spontaneously hypertensive rats. Fundam Clin Pharmacol 1995; 9: 153-160.

37. Roques BP, Noble F, Daugé V, Fournié-Zaluski MC, Beaumont A: Neutral endopeptidase 24.11: Structure, inhibition, and experimental and clinical pharmacology. Pharmacol Rev 1993; 45: 87-146.

38. Roques PB: Zinc metallopeptidases active site structure and design of selective and mixed inhibitors: new approaches in the search for analgesics and antihypertensives. Biochem Soc Trans 1993; 21: 678-685.

39. Wegner M, Kazda S, Hirth-Dietrich C, Dressel J, Voges KP, Stasch JP: Interaction of an endopeptidase inhibitor and an ANP-C receptor ligand in anaesthetized dogs. Clin Exp Hypertens 1995; 17: 861-876.

40. Wegner M, Stasch JP, Hirth-Dietrich C: Role of neutral endoeptidase 24.11 in AV fistular rat model of heart failure. Cardiovasc Res 1996; 31: 891-898.

41. Dussaule JC, Michel C, Peraldi MN: Inhibition of neutral endopeptidase stimulates renal sodium excretion in patients with chronic heart failure. Clin $\mathrm{Sci}$ 1993; 84: 31-39.

42. Smits GJ, McGraw DE, Trapani AJ: Interaction of ANP and brady kinin during endopeptidase 24.11. inhibition: renal effects. Am J Physiol 1990; 258: F1417-F1424.

43. Sybertz EJ, Chiu PJS, Vemulapalli S, Watkins R, Haslanger $M$ : Atrial natriuretic factor-potentiating and antihypertensive activity of SCH 34826: an orally active neutral metalloendopeptidase inhibitor. Hypertension 1990; 15: 152-161.

44. Hirata Y, Matsuoka $\mathrm{H}$, Hayakawa $\mathrm{H}$, et al: Role of endogenous atrial natriuretic peptide in regulating sodium excretion in spontaneously hypertensive rats: effects of neutral endopeptidase inhibition. Hypertension 1990; 17: 1025-1032.

45. Kahn JC, Patey M, Dubois-Rande JL, et al: Effect of sinorphan on plasma atrial natriuretic factor in congestive heart failure. Lancet 1990; 335: 118-119. 